\title{
P02.19. Resilience training for depressed healthcare workers: results from 2 and 12 month followup
}

\author{
J Dusek*, H Emmons, C Denton, S Masemer \\ From International Research Congress on Integrative Medicine and Health 2012 \\ Portland, Oregon, USA. 15-18 May 2012
}

\section{Purpose}

To evaluate the impact of the Resilience Training (RT) Program on depressive symptomology, QoL and presenteeism at 2 and 12 month follow-up assessments.

\section{Methods}

Forty healthcare workers with major depressive disorder were enrolled in the study. The first 20 eligible employees who responded to study advertisements were assigned to RT program. The second 20 eligible employees had an 8 week waiting period before starting the RT program. Primary outcomes were changes in depression, QoL, and presenteeism. For the RT group, questionnaires were completed before and after the 8-week RT program. The waitlist group completed questionnaires before and after an 8-week wait period and after completion of the RT. Both groups also completed the questionnaires 2 and 12 months after their completion of the RT program.

\section{Results}

Overall, 34 of the 40 participants completed the 2-month follow-up. Averaging results across all 34 participants, PHQ-9 scores dropped from 11.4 at initial baseline to 4.3 at 2 months $(\mathrm{p}<.0001)$ with $74 \%$ achieving remission (PHQ-9 of less than 5). The SF-12: mental status subscale improved from 32.4 to 47.5 ( $\mathrm{p}<.0001)$. Presenteeism decreased from $34.2 \%$ to $10.9 \%$ ( $\mathrm{p}<.0001)$. Using established procedures, this reduction in presenteeism translates to a cost savings of over $\$ 2,169$ per participant over the 2-month period. The results persisted through the 12 month assessment. Averaging results across all 24 participants who completed the 12 month follow-up, PHQ-9

\footnotetext{
Penny George Inst. for Health \& Healing, Abbot Northwestern Hospital, Allina Health, Minneapolis, USA
}

() 2012 Dusek et al; licensee BioMed Central Ltd. This is an Open Access article distributed under the terms of the Creative Commons Attribution License (http://creativecommons.org/licenses/by/2.0), which permits unrestricted use, distribution, and reproduction in scores remained low with a score of 4.6 and $67 \%$ remained in remission. SF-12 scores remained high at 46.6. Presenteeism scores remained low at $7.9 \%$ and with cost savings of $\$ 13,037$ per participant over the 1 year time period.

\section{Conclusion}

Results from both 2 and 12 month follow-up assessments demonstrate that the RT program significantly improves clinical outcomes (depression and QoL) and could provide a significant return on investment if used in a healthcare workplace setting.

Published: 12 June 2012

doi:10.1186/1472-6882-12-S1-P75

Cite this article as: Dusek et al:: P02.19. Resilience training for depressed

healthcare workers: results from 2 and 12 month followup. BMC

Complementary and Alternative Medicine 2012 12(Suppl 1):P75.

Submit your next manuscript to BioMed Central and take full advantage of:

- Convenient online submission

- Thorough peer review

- No space constraints or color figure charges

- Immediate publication on acceptance

- Inclusion in PubMed, CAS, Scopus and Google Scholar

- Research which is freely available for redistribution Submit your manuscript at
www.biomedcentral.com/submit C Biomed Central any medium, provided the original work is properly cited.

C Biomed Central 